\title{
The Franciscans Order: Global History from the Margins
}

\begin{abstract}
The Franciscan Rule dedicated its followers to wandering in the world as pilgrims and strangers, and they rapidly developed a precocious global network, yet the Franciscans' contribution to global history is more complex than the story of their early global presence. Following a Rule of poverty, Franciscans voluntarily aligned themselves with the margins, refocusing concepts of distance and inverting landscapes of the strange and the familiar. Committed to becoming strangers wherever they found themselves, they developed a unique perspective on the world that enabled an 'in oculis eorum' (seeing as others). This article contends that the Franciscans' socio-religious commitment to their Rule of poverty which made them strangers in this world helps explain their particular perspective on the world and its people. Using the frameworks of renaissance history and of the Franciscan institution it connects the Franciscans' contributions to descriptions of the people of the world and their languages between the thirteenth and sixteenth centuries and demonstrates that renaissance projects not only focused upon the margins of classical texts in Europe, but a range of physical and metaphysical margins.
\end{abstract}

\section{Key words}

Franciscans, global history, poverty, ethnography, stranger, historiography

\section{Introduction}


'The common money of these people of Cathay is a card of mulberry bark on which are stamped certain lines. Nor is this strange, since the Ruscani who are near us have as money the face of squirrels' ${ }^{i}$ In this passage, the Franciscan intellectual Roger Bacon (1214 - 1294) uses the writings of William of Rubruck (c. 1220 - c. 1293) to describe the different customs of foreign peoples and observe that they are not strange. Rubruck and Bacon were Franciscans, sworn to the Regula Bullata, approved by the papacy in 1223, which had commanded that its followers go 'as pilgrims and strangers in this world' (peregrini et advenae). ${ }^{i i}$ From the thirteenth century Franciscans journeyed across the world, to the furthest parts of Europe, North Africa, and the Middle East, becoming the first Europeans cross the silk roads to reach East Asia and the first religious order in the Americas in the early sixteenth century. As Rubruck left the edges of the Latin world and entered into the Khanate of the Golden Horde, he described himself, a Franciscan, as strange in the eyes of those he encountered: 'There we stood in our habit bare-footed, and bare-headed, and were a strange spectacle in their eye'iii ('stetimus ibi nudis pedibus in habitu nostro discoopertis capitibus, \& eramus spectaculum magnum in oculis eorum'). ${ }^{\text {iv }}$ Here we glimpse the perspective on the world and its inhabitants developed by the mendicants who dedicated themselves to the Rule of St Francis, which committed them to becoming the perennial stranger, wherever they found themselves.

Following their Rule, Franciscans travelled to the margins of the world as it was imagined by Western Europeans. Emerging first in Italy in the thirteenth century, Franciscans travelled across Europe and transcended the boundaries of Christendom, becoming a familiar sight in Muslim territories in the Near East and North Africa, establishing themselves in Northern and Eastern Europe, and travelling to China before Marco Polo. In the fourteenth century Franciscans travelled across Southeast Asia, ${ }^{\mathrm{v}}$ in the 
fifteenth century they became established in the Near Atlantic, vi and in the sixteenth century they became the first religious Order to become established in the Americas. Despite their precocious global dimensions, Franciscan history has remained on the margins of global history. Scholars of medieval and early modern history have tended to see the Franciscans' travels to the Near and Far East in the thirteenth century and their travels to Mexico in the sixteenth century separately, yet renaissance history provides a framework for tracing continuities. Renaissance history provides this framework by re-focusing our attention upon the Franciscans' contribution to renaissance projects, the quest to know the world, its people, and languages. Using Franciscan sources, this paper brings global Franciscan history out of the margins and explores the Franciscan perspective on the world and their construction of knowledge of the people of the world by comparing examples from the thirteenth and sixteenth centuries. The first part of the paper focuses on how the Franciscans' doctrine of poverty led them to identify themselves as strangers, while the second part uses this as context for understanding their contribution to understanding others. Ultimately it provides a reflection on the Franciscan perspective on the world, which refocused notions of distance and played with the boundaries of the strange and the familiar.

Franciscans travelling the world had many layers of identity. They might have been missionaries, diplomats, or ambassadors, but they were keen to describe themselves as distinctly Franciscan. For example, as Rubruck travelled to China in the thirteenth century he was sponsored by Louis IX and had diplomatic duties but in describing himself he rejected this identity: Rubruck described how his commitment to the poverty of his Order led him to subvert the norms and expectations of diplomatic exchanges which were based on gift giving, asking the Tartars to 'condescend to accept a small gift at our hands, on the grounds 
that I was a monk and it was not the custom of our Order to possess gold or silver or precious garments, which accounted for my not having any such things to offer him, but would he accept our food for a blessing' vii Descriptions such as this indicate how the Franciscans sought to set themselves apart from other global travellers on account of their idealised poverty.

While the Order comprised different individuals and different factions, the Franciscan Rule dedicated its followers to realising and representing a life of poverty. This gave the Franciscans a theological commitment to align themselves with the margins, physically and metaphysically; as Peter Brown explained, 'the poor were frequently seen to represent an extreme of the human condition, persons teetering on the brink of destruction and condemned to the outer margins of society'. viii In their writings, Franciscans depicted themselves as pioneers of the exploration of all kinds of physical and metaphysical margins. Franciscans travelled the world, but they were also on another journey, the spiritual journey to transcend the distance between themselves and God. This journey was part of the culture of mysticism that was also intrinsic to the Order and had been cultivated in particular by Bonaventure. Part of the uniqueness of the Franciscan journey was that incorporated both transcendental elements - journeying from the world - and immanent elements - journeying in the world. As the Franciscans sought to realise the Rule's mandate to become strangers, their concept of distance was not simply geographic, but also governed by Franciscan theology.

The travelogue of Rubruck in East Asia provides an example of a Franciscan seeing himself as a stranger while in places that were geographically distant from Europe, where the Order had emerged, but the Franciscans also realised themselves as 'other' within Europe. Arnold Sarrant's Chronica XXIV Generalium reported that Franciscans travelling to 
Portugal were feared to be heretics, because of their strange dress and language. ${ }^{i x}$ Following the foundational mandate of their Rule, Franciscans idealised themselves as strangers in the societies in which they found themselves, even as subversives to be feared, as robbers and as monsters. As they travelled to the margins to realise their poverty by becoming strangers, their concept of distance was not simply geographic but also social.

Franciscan realised their conversion to the Order through embodied performances as they travelled the world in poverty, 'as pilgrims and strangers'. The Franciscan performance of poverty was governed by their Rule, which stipulated how they should appear in society; it committed them to the social margins. Following the Rule, the friars not only adopted a Franciscan habit but also a Franciscan habitus: a structured system of coded identity realised through coded performances and gestures. ${ }^{x}$ Barefootedness and habits made from course cheap material were key symbols of the Franciscans' performance of poverty. The Franciscan habit was the outward gesture of their inner poverty, a poverty that transported the Franciscans to the margins of society. Aligning themselves with the margins and inventing themselves as strangers in the societies they found themselves was part of the Franciscans' habitus of the habit. According to his hagiographer Thomas of Celano, Francis had wanted his followers to appear as undesirable social outcasts and instructing that Franciscan poverty should be, like his habit, a 'thing that the world would never covet'. ${ }^{\text {i }}$ The idealised Franciscan position was not to be valourised for their poverty but to be despised for it and rejected by the world.

The Franciscans wanted their poverty to make them strangers, and to realise their poverty through this alienation. Georg Simmel, one of the founders of the field of sociology in the late nineteenth and early twentieth century, was interested in the phenomenon of the stranger. Simmel noted the similarity between the stranger and the poor and 
commented upon and their placement in society, observing that 'the stranger, like the poor and like sundry "inner enemies," is an element of the group itself'. The stranger and the poor disrupt landscapes of familiarity and re-calibrate perspectives of distance. Strangers, like the poor, are within society; realising this, the geographic boundaries of a society are not important. Pursuing an ideal of poverty, Franciscans played with the boundaries of the strange and the familiar, and this gave them a unique perspective on the people they encountered as they travelled the world 'as pilgrims and as strangers'.

Looking at European medieval travel literature or other depictions of the world such as mappamundi we know that many people in medieval Europe held the worldview that the further from the centre of the known world, the stranger the world became, and the edges of the world were inhabited by the monstrous races. xii The first people to travel from Europe to these edges were the Franciscans. William of Rubruck set out across Central Asia to Mongolia in 1253, and yet as he crossed these unknown lands, a journey that took two years, he did not emphasise descriptions of monsters and strange creatures, ${ }^{\text {xii }}$ unlike Marco Polo whose later travels were memorialized in /l Milione and described many fantastic beasts including serpents, monopods, cynocephali, and other monsters. ${ }^{\text {xiv }}$ Instead, Rubruck inverted this familiar trope, writing that 'the men [Tartars] surrounded us and gazed at us as if we were monsters, especially because we were bare-foot' ${ }^{\mathrm{xv}}$

Shirin Khanmohamadi recognized the significance of Rubruck's perspective, contending that 'the Journey's destabilization and interpenetration of various cultural and religious boundaries further attests to the rather open and fluid nature of premodern Europe's boundaries with its cultural and religious others that characterizes writing ethnography before empire and before the rise of Orientalist representation' ${ }^{\text {xvi }}$ Khanmohamadi contextualises Rubruck's perspective with other medieval ethnographers, 
contending that medieval authors displayed 'an uncanny ability to see and write from the perspective of the others whom they mean to describe', and that they see 'relationally, dialogically, from more than one vantage point'. ${ }^{\text {vii }}$ However, she does not find other examples of the recognition of self as other, which I would argue, is not generically medieval, but specifically Franciscan. Maurizio Peleggi also recognised the importance of the Franciscan perspective on the world, describing medieval Franciscan travelogues as 'proto-ethnography'..viii Jás Elsner and Joan-Pau Rubiés also note the 'unprecedented ethnographic analysis' present in the narratives of the thirteenth-century Mongol missions of the Franciscans John of Piano de Carpini and William of Rubruck. ${ }^{\text {xix }}$ Yet we risk romanticising the Franciscan Order if we fail to recognise that we learn more about the ethnocentricism of the Franciscan perspective than we do about the people of the world from Franciscan sources.

'There we stood in our habit bare-footed, and bare-headed, and were a strange spectacle in their eye ${ }^{\prime x x}$ ('stetimus ibi nudis pedibus in habitu nostro discoopertis capitibus, \& eramus spectaculum magnum in oculis eorum'). ${ }^{x \times i}$ When Rubruck describes himself as strange in the eyes of the people from distant lands whom he encounters, he does so by describing himself as a Franciscan, 'in our habit bare-footed and bare-headed' ('stetimus ibi nudis pedibus in habitu nostro discoopertis capitibus'). Khanmohamadi argues that Rubruck's 'seeing as other' (in oculis eorum) is a missionary gaze, part of the necessary perspective of someone with a conversion agenda: 'the reciprocal gazes of conversion and its work of incorporation ideally require the opposite [of the imperial gaze which objectifies]: the humanization of would-be converts, and conversely, the making of a public display of a preacher who must extend himself, whatever the subjective risks, toward the other - an ever-changing audience - in the name of salvation'. xxii Yet the Franciscans' unique 
perspective on the world cannot be simply explained through their desire to convert others, the first conversion of the Franciscan was the conversion of himself to the Franciscan Rule. As Bert Roest also observed, the Franciscans might be in the world to convert the 'other', but they had a dual purpose to convert the self, and to overcome it..xiii

The Franciscans conversion to the Rule of poverty and invention of themselves as strangers was a complex process. To achieve this they used another tool from their theological toolkit: humility. When thinking about the role of humility in the history of the Franciscan Order I do not wish to eulogise the Franciscan global activities as humble or peaceful, but rather to signpost one of the theological concepts with which they experimented in pursuit of their ideology of poverty. Within Christian theology humility is a virtue, signifying submissiveness and a poverty of self, a rejection of vanity, and a lowering of oneself compared to others. Humility was a strategy for realising the Franciscan idea of poverty by overcoming the self. The Franciscan concept of poverty was continuously contested from the early years of the Order and vitriolic disputes about the correct interpretation of poverty characterised the history of the Order. ${ }^{x i v}$ The more extreme Franciscan position interpreted poverty as an annihilation of self. Franciscans advocating this interpretation of poverty could refer to the Admonitions of their founder, where Francis had told his followers to hate their bodies, since 'each one has the enemy in his power, that is his body through which he sins'. ${ }^{x \times v}$ Maurizio Peleggi has also observed that the Franciscans' 'programmatic humility' distinguished them from the other mendicants and made them more prominent. ${ }^{x x i}$ Humility is important for understanding the Franciscans' perspective on the world.

The Franciscan tradition of humility was explained by Bonaventure, who argued that one of the pathways to humility was 'just assessment of oneself'. ${ }^{x x v i i}$ As the Franciscans 
travelled the world, following their Rule's command to go 'as pilgrims and strangers in the world', they learned much about the world and its peoples, yet the Franciscans commitment to humility meant that they had a journey not only to know others, but also themselves. From the thirteenth century the Franciscans produced knowledge about the people and places of the world, but they also situated themselves as an object of study, reflecting on how they saw and knew, and seeking to know themselves. ${ }^{\text {xxviii }}$ This quest to understand humanity, starting with one's self was part of a framework of Spiritual Franciscan thinking; as the Spiritual Franciscan Angelo Clareno instructed those Franciscans who tried to understand the world: 'know yourself first'. ${ }^{x x i x}$ Franciscans travelled the world from the thirteenth century producing detailed descriptions of the people of the world, but they were also committed to deepening their knowledge of themselves at the same time. In her book What is Global History? Pamela Crossley observed the contemporary writing of global history was flawed as 'global history as an intellectual enterprise is a production of European and American historians who can never make themselves the object of study'. ${ }^{x x}$ The global history produced by the Franciscans from the thirteenth century differs as the Franciscans pursuit of poverty through humility and estrangement meant that the Franciscans were committed to the double quest of knowing themselves as well as others.

Understanding the theological dimensions of the Franciscan Order, the quest to realise their ideal of poverty through estrangement and humility provides an important context for understanding the Franciscans' particular contribution to the knowledge of the people of the world and their languages, which will now be explored in the second part of this paper.

Franciscans disrupted comfortable landscapes of the strange and the familiar. Just as they estranged themselves, so they meticulously described others and rendered the 
unknown familiar. As Rubruck travelled across central Asia, deep into the lands of the Mongols, he carefully described the different peoples and their customs. The travelogues produced by Franciscans had their own journey as they then circulated across the network of Franciscan houses. Rubruck's writings became an important source for Roger Bacon, who contributed to the Franciscans' highly differentiated knowledge of the world: 'we see that all things vary according to different localities of the world not only in nature, but also men in their customs; since the Ethiopians have one set of customs, and the Spaniards another, and the Greeks yet another. ${ }^{\prime x x i}$ As the opening quotation sought to illustrate, from the Franciscans' perspective, the customs of people may vary, but they were not strange. $W . R$. Jones explored how Bacon contributed to the medieval discourse of 'barbarians'xxxii but, crucially, Bacon offered a highly differentiated image of the world which drew upon the writings of his fellow Franciscans.

The inversion of familiar landscapes of identity that we find in the writings of Rubruck in the thirteenth century are echoed in the writings of a Franciscan writing three centuries later in the Americas, by Fray Cristóbal Cabrera (1513-1598) who wrote 'here I am

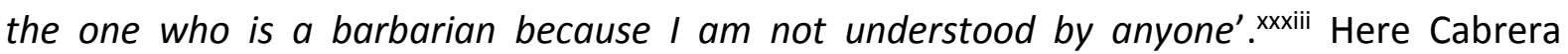
illustrates the Franciscan perspective of inverting the landscapes of the strange and the familiar, but this also points towards something that was vital to the Franciscans' quest to know the people of the world, language.

When Cabrera described himself as a barbarian because he was not understood by anyone, he invoked the Franciscan tradition of seeing themselves as strangers, but he also invoked the long Franciscan tradition of interest in languages and the important of language. As Bacon had explained, knowledge of languages was a gateway to knowledge of the world: 'many famous roots of knowledge depend on the mastery of the languages 
through which there is an entrance into knowledge on the part of the Latins'.$^{x x x i v}$ On a quest to know the people of the world, Franciscans became pioneers in the study of foreign languages and translation and methodologies of dialogue. The Franciscan efforts with languages stemmed from their ethnocentric desire to preach and convert the peoples of the world, but these efforts also oiled the cogs of the first cross-cultural global conversations.

Drawn to the margins of the Latin world, the Franciscan network became a hub of linguistic and translation knowledge. Franciscans who did not know Arabic met frustrations in Islamic territories in the Iberian Peninsula, the Balearics, and Northern Africa. This led the Catalan Franciscan tertiary Ramon Lull (c. 1232 - 1315) to establish a language school in Mallorca for the Franciscans and to encourage learning Arabic. Missionaries who focused on this linguistic study belong to the Lullian school. Franciscans were not only dedicated to learning Arabic and translating their writings into Arabic, but in all the languages of the regions they encountered.

The Codex Cumanicus is testament to the way in which the institutional structure of the Franciscan Order facilitated their contribution to knowledge of the languages of the world. The Codex Cumanicus was compiled around 1292-1294 and circulated between different libraries where different parts were added; the first parts were made in the Crimea and compiled in Italy, the codex then travelled to Germany were further parts and marginalia were added, and the manuscript then ended its journey in Venice. The first copy of this manuscript was then made in 1303 in a Franciscan monastery in South Russia (Gabain) by German Franciscans. The original author of the early parts of the codex is not known (but had knowledge of both Coman and Persian), but it was compiled by a team of Franciscans, probably of different nationalities. ${ }^{\mathrm{xxxv}}$ The network of Franciscan houses facilitated the movement of scholars, skills, and manuscripts which enabled the Franciscans 
to collaborate and build up a compendium of linguistic knowledge. Felicitas Schmeider contextualises this within a Franciscan tradition of linguistic knowledge, observing that Ramon Lull's ideas about language were widely discussed at the times of the production of the Codex Cumanicus. ${ }^{x x x v i}$ The second part of the Codex Cumanicus clearly serves the Franciscans' cause and contains hymns translated into the Cuman language, but the compendium was also used by merchants, especially those requiring knowledge of Persian and Cuman, and we should recognise the Franciscan contribution to early cross-cultural conversations.

This tradition of language learning was strong in the Franciscan Order, and helps explain the linguistic acumen of the first Franciscans in the Americas. When the Jeronymite friar Ramón Pané wanted to produce his description of the New World, ${ }^{x x x v i i}$ he turned to the Franciscans for help, ${ }^{\mathrm{xx} x v i i i}$ and this is unsurprising considering the tradition for language learning within the Order. The sixteenth century Franciscan Diego de Landa described how Fray Luis de Villalpando indigenous languages by signs and small stones, deduced a grammar and wrote out the tenets of the Christian doctrine. ${ }^{\text {xxix }}$ Another Franciscan, Andrés de Olmos, produced the first grammar of the Nahuatl language, ${ }^{x l}$ Alonso de Molina produced one of the first dictionaries of the Nahuatl language, and Jacobo de Testera designed a system of hieroglyphics using Nahua glyphs to teach the catechisms. ${ }^{\text {li }}$ In 1536 Juan de Zumárraga established the Colegio de Santa Cruz in Tlatelolco, which used the model of the Franciscan seminary to indoctrinate indigenous Amerindians. The 'conversations' that the Franciscans developed in the Americas reflected the different context of the sixteenth century, where language became, as the famous Spanish humanist Antonio de Nebrija had observed, the 'ideal companion of Empire', xlii and a symptom of 'the

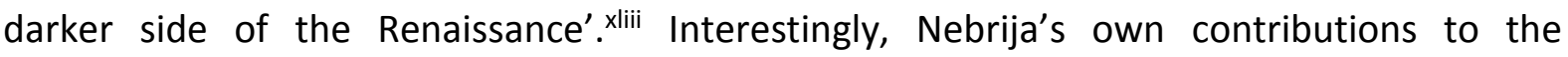


standardisation of Castille had been commissioned by the powerful Franciscan Francisco Jiménez de Cisneros, reminding us of the Franciscans multidimensional dedication to infiltrating language systems.

The Franciscans used intermediaries to acquire their knowledge of languages. In the Balearics in the thirteenth century, Ramon Llull learned Arabic from his Muslim slave, whom he later killed. ${ }^{\text {xiv }}$ In the Black Sea region, intermediaries were essential to compile the compendium of knowledge of the Kipchak languages. In Karakorum, William of Rubruck was aided in his study of the Mongol language by an Armenian monk and one of the wives of Mangu. In the Americas, Franciscans used indigenous converts in their missions to learn Nahua, and Sahagún used a workshop of indigenous workers, who had been educated in the Franciscan college of Santa Cruz, to produce the monumental Florentine Codex.

The Franciscans were not only developing knowledge of the languages and customs of the peoples of the world, they also contributed to the history of the technique of dialogue. The idea that the Franciscans were the vanguards of interfaith dialogue is partly connected to the mythology of the Order, a tradition that is continued by some Catholic writers today, for example, Luigi Bressan recently wrote that the pope selected Franciscans as papal legates to the Far East in the thirteenth century as they had a tradition of dialogue established by their founder. xlv Yet, as Cary J. Nederman also observed, xlvi it was not by coincidence that it was the Franciscans that set out to understand and converse with the Mongols in the thirteenth century. The Franciscans did make an important contribution to the history of dialogue, and other arts of persuasion fitting to their roles as missionaries and inquisitors. Daniels argues that 'the rediscovery of Aristole and development of scholasticsm helped spur Peter the Venerable, Ramon de Penyafort, Roger Bacon, and Ramon Llull to attempt to devise an apologetical and philosophical theology which missionaries, trained 
also in non-Christian languages, could employ to learned Jews or Muslims. 'xlvii Ramon Llull's Liber de gentili et tribus spaientibus (c. 1275) was a particularly important contribution. The presence of a fifteenth century manuscript of Lull's Declaratio Raymundi per modum dialogi in the Canary Islands illustrates the spread of Lull's linguistic technique from the Mediterranean world to the Near Atlantic in the late Middle Ages. ${ }^{\text {xlviii }}$ Louise M. Burkhart explored the unique Franciscan contribution to the strategy of dialogue with the Nahua in sixteenth-century Mexico and reminds us that their ultimate aim was 'to resolve dialogue into monologue, to replace cultural diversity with conformity', but that in this they failed due to the vibrancy and resistance of Amerindian culture. ${ }^{x \text { lix }}$

It is difficult to trace how these Franciscan attempts at dialogue were received by non-Christians, especially in places where missions were transient. The Franciscan travelogues from the late Middle Ages offer descriptions of the people and places they passed; yet Franciscans did not always simply pass through places and describe them but stayed and interacted with different people in different localities, often over long periods of time. Odoric da Pordenone, for example, stayed in Khanbaliq for three years between 1324 and 1326. Before arriving there he came across a Franciscan convent that had already been established in Yangzhou. We have limited knowledge of the Franciscans global interactions in each localities beyond the travelogues, however the tombstone of a 'Katerina', who died in 1342 at the site of a Franciscan mission in Yanzhou, gives some clues. The precise identity of Katarina is unknown, but it is thought that she may have been at least partly European. The tombstone, would have been an unusual sight in fourteenth century China. It is testament to a transcultural interaction, while its inscription was in Latin, the art historian Frances A. Rouleau describes the two angels which also appear on the tombstone as 'a striking mixture of Eastern and Western iconographic convention'.' When it came to the 
depiction of human forms, on the one surviving material source we have from the fourteenth-century Franciscan missions to China, there was evidence of some cultural dialogue, some attempt to represent plurality and local difference.

Without romanticising the Franciscans, one could argue that the Franciscans' theoretical humility also created a window of opportunity for transcultural interactions, and Franciscans were themselves influenced by the cultures and languages with which they engaged. The Rule had committed Franciscans to travelling the world in poverty and humility as strangers. It is perhaps through the performance of their own inferiority, a purposeful and utilitarian lowering of oneself compared to others, that they were able to find points of communication. While, as we have noted, it difficult from Franciscan sources to know anything about how the friars and their ideas were received in the cultures they encountered, we can find evidence of transcultural interactions within the history of the Order. For example, Ramon Lull was not only interested in strategies of translation and dialogue and the Arabic language but also in Islamic philosophy. He made his own translation of Maqâsid al-falâsifa (Opinions of the Philosophers), and was influenced by Arabic logic. Charles Lohr has argued that Lull's interest in Arabic thought gave him an important role in the history of Western thought, suggesting that he was more in line with Islamic scholastics than his Christian scholastic contemporaries. Ii Interest in Arabic science can also be found in the work of Roger Bacon. Later in the thirteenth century Franciscans became established in Bosnia, and continued to occupy parishes in Hungary after its conquest by Turkey in the sixteenth century. István Tóff contends that they were the only Catholic institution to be tolerated by the Turks and the best able to cope with the diverse ethnic-linguistic map of Eastern Europe. ${ }^{\text {lii }}$ Further, Franciscans must have been open to 
transcultural interactions in this region as there was a reasonably high rate of conversion to Islam amongst Bosnian Franciscan intellectuals. ${ }^{\text {liii }}$

As previously touched upon, the Franciscans' quest to know the people of the world and their languages continued in the Americas in the sixteenth century. Three centuries after Rubruck, Bernardino de Sahagún (1499-1590), undertook the journey across the Atlantic to the newly discovered Americas were he produced extensive writings about the people who lived there, just as members of his Order had done across Eurasia. Sahagún's Florentine codex, or Historia general de las cosas de Nueva España (General History of the Things of New Spain), was a monumental twelve volumes describing the cultural, economic, religious, and bodily practices of the Aztecs. Sahagún worked with Amerindians to produce these texts, and Miguel León-Portilla contended that with his innovative ethnographic methods, Sahagún should be seen as the father of modern anthropology. ${ }^{\text {liv }}$ The Franciscans' energetic contributions to descriptions of the peoples, languages and customs of the world have generated interest and debate. Walden Browne noted the importance of Sahagún's contribution to knowledge of the people of the world, but contended that Sahagún was too embedded in medieval thought systems to be the father of modern anthropology. ${ }^{\text {Iv }}$ This medieval/modern caesura is an artificial rupture that veils our understanding of the past in the ideology of the present, while the history of the Franciscan Order offers another way to contextualize the Franciscans' contribution to knowledge of the language and peoples of the world in relation to their perspective on the world.

Franciscan history provides a way for historicising the Franciscans' contribution to global history, their construction of a perspective on the people of the world and contributions to the history of knowledge of languages and translation, but this historicisation does not imply a straight forward continuity. The people whom the 
Franciscans encountered in the Americas were not those they had encountered in Eurasia, and the missionary context had changed. For example, apocalyptic fervour had long driven the Franciscans' desire for conversion, but their eschatological framework had developed, as they interpreted the Americas as a fresh sign that the end of the world was coming and that they, the barefooted friars predicted by the prophet Joachim of Fiore, were the special agents dedicated to usher in the final age before the arrival of the anti-Christ. The Franciscans that travelled to the Americas in the sixteenth century were products of their time like any historical actors, but they were still linked through their institutional processes, especially the coding of their Rule, to a transhistorical notion of Franciscan identity. And, in the Americas in the sixteenth century, the Franciscans continued to subvert the normative boundaries between the familiar and the strange and to generate a unique perspective on the world that was driven by their commitment to realise their doctrine of poverty.

While sixteenth-century 'encounter' narratives often described the differences between Europeans and Amerindians, for example, certain Caribbean Islanders were repeatedly described as cannibals, ${ }^{\text {,vi }}$ Franciscans often emphasised similarity and observed that they had much in common with the Amerindians and that they shared certain practices and values. For example, according to Motolonía, 'when the president of the audiencia [Don Sebastián de Fuenleal] asked the Indians why they knew and loved [the Franciscans] and were beloved by them' they answered, 'because they go about poor and barefoot like us, eat what we eat, live amongst us, and their talk among us is gentle'. ${ }^{\text {lvii }}$ Reports such as this indicate the Franciscans idealised perception of themselves.

The Franciscans continued their play with the boundaries of the strange and the familiar in the Americas, and they developed a Franciscan perspective on the European encounter with the Americas that did not subscribe to the binary model of conquering 
Europeans and indigenous subjects. The sixteenth-century Franciscan chronicles built the idea that the Franciscans and the Amerindians had a shared identity based on poverty were therefore together against the Spanish and subject to the same violence at the hand of the

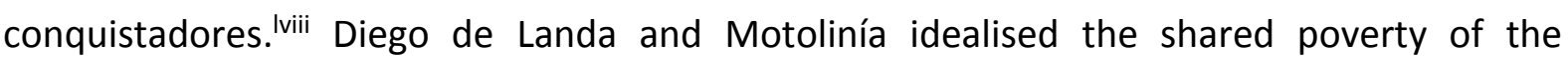
Amerindians, and depicted how the Franciscans were at odds both with the Spanish soldiers and the clergy, and were persecuted by them along with the Amerindians. lix Motolinía wrote that the Amerindians 'should not be denied what they want, for theirs is the kingdom of heaven, since in the matter of worldly goods they barely achieve a wornout bit of matting to sleep on or one good blanket to cover them, and the poor hut they live in is tumbled down and open to dampness at night'. ${ }^{1 x}$

In their textual accounts of their encounters with the New World Franciscans again played with the boundaries of the familiar and the strange, the civilised and the barbarian. The Oroz Codex described the Amerindians who martyred Fray Bernardo Cosin as barbarians: '[Cosin] was slain by those inhuman barbarians called Chichimecas because the demon, envious of the salvation of souls, would not allow these poor ones to escape his power and captivity'. Ixi It is interesting that the term Chichimecas was used here by the Franciscans; this word refers to the semi-nomadic groups of Mexico, but is the Nahua approximate for the European term for barbarian. Even when describing a 'barbarian' that killed a Franciscan friar, the account continues that these barbarians must be known: 'and so that we may know what people these chichimecas are, it occurred to me to enter their identity, customs, and religion in this place, so that when the curious reader should encounter the term "chichimeca" in this history, he can refer to this place and read this digression which we will make here, and he will learn about the ferocity and bestial life'. .xii $^{\text {. }}$ The Franciscan chronicle describes the chichimecas as barbaric and bestial, but also as 
barefoot, the symbol of the Franciscan condition. ${ }^{\text {Ixii }}$ Franciscans were perennially playing with the boundaries of strangeness.

The Franciscans continued their quest to realise their doctrine of poverty in the Americas through their discourse and performances of humility, a denial of self, and this continued to challenge the increasingly charged boundaries of the strange and the familiar. During the sixteenth century the identity of the Amerindians became a hot topic as the Spanish conquistadores and their intellectual apologists wanted to ascertain whether the Amerindians could be enslaved. The debates pivoted around the question of whether the Amerindians rational enough to be converted or were natural slaves. ${ }^{\text {xiv }}$ Meanwhile the first Franciscans travelling to the Mexico were commanded 'become madmen to the world, you might convert the world by the foolishness of your preaching'. ${ }^{\mathrm{xv}}$ In the instructions given to the these first Franciscans by the Minister General, Franciscans were reminded not only that they should be 'the last among the rest, treading and trampling upon the glory of the world' but also that they should be 'despised for littleness and idiocy, possessing the sublimest poverty, and in such a way that the world should regard you with mockery and contempt, and the very picture of contempt and derision, and should consider your life madness and your end without honor'. Ixvi

The Franciscans saw the world through the prism of their norm-inverting poverty. In Europe, Franciscans found 'great treasure' in being mistaken for social dissidents, as heretics and robbers, because of their poverty. ${ }^{\mid x v i i}$ The gold mines, a victorious discovery for the conquistadores, were 'a plague on the Amerindians' for Motolinía. Ixviii The Franciscans' inverting gaze continued in other ways. Mendieta described the powerful Spanish conquistador Henan Cortés, who had appropriated Mexico for the Spanish, as 'so poor and humble, so deprived of the world' ('tan pobres y humildes, y tan despojados del mundo'). .xix $^{\text {. }}$ 
At the same time that these Franciscan chroniclers were writing their alternate accounts of the conquest of the Americas, Sahagún was producing his monumental description of the Amerindians, their ideas, and their customs. As Sahagún sought to render the Amerindians as familiar, he wrote that the greed of the conquistadores turned them into animals: '[the conquistadores were] gladdened. As if they were monkeys they seized upon the gold. It was as if their hearts were satisfied, brightened, calmed. For in truth they thirsted mightily for gold; they stuffed themselves with it; they starved for it; they lusted for it like pigs'..$^{x x}$ Close to the margins as always, Sahagún's Florentine Codex was deemed to contain too much knowledge of non-Christians and it was condemned, becoming a secret of the renaissance world in the sixteenth century. ${ }^{\mid x x i}$ The Franciscans' doctrine of poverty gave them a unique perspective on the world, but this was not a perspective that would enter the mainstream, but would remain at the margins.

In conclusion, this article sought to not only to bring the Franciscans out of the margins of global history, but to show how their view from physical and metaphysical margins led the Franciscans to have a unique perspective on the world. It used the framework of the institution and of renaissance history to historicise their contribution to global history in a way which disrupts familiar spatial and temporary geographies. Hans Baron first recognised the importance of the Franciscan Order to the emergence of the renaissance in the thirteenth century, challenging the Burckhardtian notion that the renaissance was a rupture from the Middle Ages, and demonstrating the importance of Franciscan values to the project of humanism. ${ }^{\text {Ixxii }}$ Baron's work still resonates in debates in the field of renaissance studies decades after its publication. As Alison Brown also observed, Baron used the Franciscans to challenge Burckhardt's notion of the individual and demonstrate the importance of social context and to broaden our understanding of 
renaissance projects. Ixxiii In this article we see that the Franciscans' contributions to understanding the world, its people and its languages did not end in the late Middle Ages and that it was not confined to Trecento Italy but was a global project which stretched into the early modern period.

Many global histories that have incorporated religious orders have focused on Jesuits missionaries, beginning in the mid-sixteenth century. Yet, with their regula vitae, commitment to travel, network of convents spanning the world, and commitment to describing the people of the world and their languages, the Franciscans were the first global Order. Yet, transcending the margins of the Latin world from the late Middle Ages, the Franciscans did not only seek to learn the languages and customs of the people of the world but to understand themselves as well as others. The Franciscan gaze on the world inverted familiar landscapes: they wanted to be seen as heretics and poor in Europe, monsters in the Far East, and poor like the Amerindians in the Americas. This self-othering came from their pursuit of their complex ideas of poverty, which was governed by their Rule and involved a programmatic humility and an invention of oneself as the stranger, and this in turn gave the Franciscans a unique perspective on the world.

The Franciscan commitment to poverty, defined by their Regula vitae which instructed them to go 'as pilgrims and strangers in this world' not only de-territorialised the Franciscans and enabled them to develop a global network, but dis-located them from familiarity with the societies in which they found themselves. This re-focused their perspective of the familiar and the strange, the near and the distant. Georg Simmel explained that 'the unity of nearness and remoteness involved in every human relation is organized, in the phenomenon of the stranger'. From the Middle Ages the Franciscans tapped the sociological power of the stranger, aligning themselves with the margins both 
within and beyond the Latin world, and questioning the spaces of human difference. When they were concerned with distance it was not the distance between China and Rome, or America and Assisi, but the distance between themselves and God. Simmel contended that the stranger 'reveals that spatial relations are only the condition, on the one hand, and the symbol, on the other, of human relations'. Ixiv Travelling to the margins both within Europe and across the world and making themselves strangers, Franciscans were concerned about what it meant to be human, for both themselves and for others. This facilitated their in oculis eorom perspective and led to their striking descriptions of the world and its people. Given the originality of some of their descriptions it is not surprising that contemporary commentators have debated whether their contributions were medieval or modern, but Franciscan history offers an alternate method of historicisation that transcends conventional periodisation.

Scholars may debate whether a diachronic history of an institution comprised of diverse individuals encountering differing and contingent contexts is dehistoricising, but the case of the Franciscans who used their doctrine of poverty as a tool to disrupt received landscapes of the strange and the familiar, who described themselves as they described others, and who consciously played with concepts of distance, merits exploration. It signposts new directions in global history which go beyond the dialectics of the outside and inside. As Gaston Bachelard explained, 'the dialectics of here and there has been promoted to the rank of an absolutism according to which these unfortunate adverbs of place are endowed with unsupervised powers of ontological determinism' ${ }^{\text {Ixxv }}$ Franciscan history offers new directions since their idealised poverty, codified in the Rule, was a perennial placelessness, which located them between the here and the there, between the strange and the familiar. Transcending these binaries is a useful starting point for reflecting on ones 
point of analytic departure, critiquing the ethnocentricity of all perspectives on the world, and expanding the field of enquiry by realising the permeability of the boundary between the inside and the outside, both physically and metaphysically.

\footnotetext{
'Bacon, Roger, Opus Majus, trans. Robert Belle Burke (Philadelphia, 1928), 387.

ii Regula Bullata, 'The Later Rule', in Francis of Assisi: Early Documents, Vol. 1, The Saint, eds Regis J. Armstrong, O.F.M. Cap., J. A. Wayne Hellman, O.F.M. Con., William J. Short, O.F.M., (New York, 1999), 99-106, 103. This was an amended version of the Regula non bullata of 1221; 'The Earlier Rule (The Rule Without a Papal Seal)', in Francis of Assisi: Early Documents, Vol. 1, The Saint, 63-86.103.

iii William of Rubruck, Itinerarium fratris Willielmi de Rubruquis de ordine fratrum Minorum, Galli, Anno gratia 1253 ad partes Orientales, in C. Raymond Beazley ed., The texts and versions of John de Plano Carpini and William de Rubruquis: as printed for the first time by Hakluyt in 1598, together with some shorter pieces (London, 1903), 218.

iv William of Rubruck, Itinerarium fratris Willielmi de Rubruquis, Hakluyt ed., 172.

${ }^{\vee}$ See Odoric of Pordenone, The Travels of Odoric, in Henry Yule and Henri Cordier eds, Cathay and the Way Thither, Vol. I (London, 1866) 43-162.

vi See Julia McClure, The Franciscan Invention of the New World (Palgrave, 2016).

vii William of Rubruck, 'The Journey of William of Rubruck', in Christopher Dawson ed., The Mission to Asia: narratives and letters of the Franciscan missionaries in Mongolia and China in the thirteenth and fourteenth centuries (London, 1980), 89-220, 109.

viii Peter Brown, Through the Eye of A Needle, Wealth, the Fall of Rome, and the Making of Christianity in the West, 350-550 AD (Princeton, 2014), 77.

ix 'qui, cum ad regnum Portugalliae devenissent, videntes eos populi habitu singularis formae indutos, lingua extraneos, timentes, ne essent haeretici, eos male receperunt et habitare inter se nullatenus permiserunt'; Chronica XXIV Generalium Ordinis Minorum, ed. Fr. Bernardi A Bessa, in Analecta Franciscana, sive Chronica Aliaque Varia Documenta ad Historiam Fratrum Minorum Spectantia, ed. a partibus collegii S. Bonaventurae, Vol. III (Florence, 1897), 10.

${ }^{x}$ For more on habits see Pierre Bourdieu, Outline of a Theory of Practice (Cambridge, 1997).

xi Thomas of Celano, The Life of St Francis by Thomas of Celano (Vita Prima), in FA; ED, Vol. 1, 180-308, 202.

xii For more on this topic see John Block Friedman, The Monstrous Races in Medieval Art and Thought (Syracuse, 2000).

xiii For a comparative of the description of monsters in travel writing of the European Middle Ages see Mary B.

Cambell, The Witness and the Other World: Exotic European Travel Writing, 400-1600 (Cornell, 1991).

xiv There are countless versions of Marco Polo's I/ Milione. The oldest is perhaps Liber de mirabilibus mundi, scriptum in civitate lanuae, Biblioteca Ambrosiana, 77- 135.

xv William of Rubruck, Dawson ed., 150.

xvi Shirin A. Khanmohamadi, In Light of Another's World, European Ethnography in the Middle Ages (Philadelphia, 2014), 59.

xvii Ibid, 2.

xviii Maurizio Peleggi, 'shifting alterity: the Mongol in the visual and literary culture of the late middle ages, in James Muldoon ed., Travellers and Intellectuals, and the world beyond medieval Europe (Farnham, 2010), 311$329,313$.

xix Jás Elsner and Joan-Pau Rubiés, 'Introduction', in Voyages and Visions, towards a cultural history of travel (London, 1999), pp. 1-56, p. 31.

xx William of Rubruck, Hakluyt ed., 218.

xxi Ibid, 172.

xxii Khanmohamadi, In Light of Another's World, 86.
} 
xxiii Bert Roest, 'Converting the Other and Converting the Self: Double Objectives in Franciscan Educational Writings', in lan Wood and Guyda Armstrong eds, Christianizing Peoples and Converting Individuals (Turnhout, 2003), pp. 295-301.

xxiv For a summary of these poverty disputes see Gál, G., and Flood D., eds, Nicolaus Minorita, Chronica: documentation on Pope John XXII, Michael of Cesena and the Poverty of Christ with summaries in English: a source book (New York, 1996).

${ }^{x \times v}$ The Admonitions, in Francis of Assisi, Early Documents, Vol. I, 128-137, 132.

xxvi Maurizio Peleggi, 'shifting alterity', 315.

xxvii Bonaventure of Bagnoregio, The Evening Sermon on Saint Francis, 1255, in Francis of Assisi: Early Documents, Vol. 2, 522

xxviii As the Franciscan scholar Michael F. Cusato has also observed, even when the Franciscans were writing hagiographies of St Francis they were actually caught up in their quest to describe themselves; see Michael F. Cusato, 'Talking About Ourselves: the shift in Franciscan writings from hagiography to history (1235-1247), Franciscan Studies, 58 (2000), 37 - 75, 38.

xxix Angelo Clareno, A chronicle or history of the seven tribulations of the Order of Brothers Minor (New York, 2005), 98.

xxx Pamela Crossley, What is Global History? (Cambridge, 2008), 103.

xxxi Roger Bacon, Opus Majus, trans. Robert Belle Burke, 1 (Philadelphia, 1928), 159.

xxxii W. R. Jones, "Image of the Barbarian in Medieval Europe", Comparative Studies in Society and History, 13, 4 (1971): 376-407, 398.

xxxiii Cabrea, Ad Fratrem Hieronymum Franciscanum extemporale Carmen in adolescentia, ms. Vat. Lat. 1165, verses 49-64, in Andrew Laird, 'Franciscan humanism in post-conquest Mexico: Fray Cristóbal Cabrera's epigrams on classical and Renaissance authors (Vat. Lat. 1165'), in Studi Umanistici Piceni 33 (2013), 195-211, 206.

xxxiv Roger Bacon, Opus Majus, 116.

xxxv Louis Ligeti, 'Prolegomena', Codex Cumanicus, ed. G. Kuun (Budapest, 1981), 1-54, 13

xxxvi Felicitas Schmieder, 'The world of the Codex Cumanicus, the Codex Cumanicus in its world', in II codice cumanico e il suo mondo: atti del colloquio internazionale, Venezia, 6-7 Diciembre, 2002 (Rome, 2005), pp. xiiixxxi, p. xxvii.

xxxvii Ramón, Pané, Relación acerca de las antigüedades de los Indios, edited by J.J. Arrom (8th edn, Mexico and Buenos Aires, 1988).

xxxviii David Abulafia, The Discovery of Mankind, Atlantic Encounters in the Age of Columbus (New Haven, 2008), 133.

xxxix Diego de Landa, Relacion de Las Cosas de Yucatan, Miguel Rivera ed. (Madrid, 1985), 68.

${ }^{\mathrm{xl}}$ Andrés de Olmos, Arte de la lengue Mexicana: concluido en el convent de San Andrés de Ueytlalpan, en la provincial de la Totonacapan que es en la Nueva España, el 1 de enero de 1547, ed. Miguel León-Portilla (Madrid, 1993). See also, Louise M. Burkhart who notes the importance of the Franciscans in establishing dialogue with the Amerindians in the Americas in The Slippery Earth, Nahua-Christian Moral Dialogue in Sixteenth-Century Mexico (Tuscon, 1989).

xli Jacobo de Testera, Catecismo Testerino, JCB, Codex Ind 24.

xlii "que siempre la lengua fue compañera del imperio"; Antonio de Nebrija, Gramática de la lengua Castellana, ed. Antonio Quilis, Madrid: Sociedad General Español de Libería, 1992, 74.

xliii See Walter Mignolo, The Darker Side of the Renaissance, Literacy, Territoriality, and Colonization $\left(2^{\text {nd }}\right.$ edn Michigan, 2003).

xliv The story is that Llull struck his slave for blaspheming, the aggrieved slave plotted revenge, Llull then stabbed him in self-defence and the slave died in prison as Llull pondered his fate.

xlv For example, L. Bressan, 'Odoric da Pordenone (1265-1331). His vision of China and South-East Asia and his contribution to relations between Asia and Europe', Journal of the Malaysian Branch of the Royal Asiatic Society, Vol. 70, No. 2 (273) (1997), pp. 1-23, p. 5.

xlvi Cary J. Nederman, Worlds of Difference, European Discourses of Toleration, c. 1100 - c. 1500 (Pennsylvania, 2000).

xlvii Emmett Randolf Daniel, The Franciscan concept of mission in the High Middle Ages (Lexington, 1975$), 1$.

xlviii See Enriquez-Manuel Pareja Fernández, El Manuscrito Luliano Torcaz I, del seminario de Canarias (La Laguna de Tenerife, 1949).

xlix Burkhart, The Slippery Earth, 9. 
' See Francis A. Rouleau, 'The Yangchow Latin Tombstone as a Landmark of Medieval Christianity in China', Harvard Journal of Asiatic Studies, 17:3/4, 1954, 346-365, 355.

"Charles Lohr, 'The Arabic Background to Ramon Lull's Liber Chaos (CA. 1285)', Traditio, 55, 2000, 159-170, 160.

lii István Tóff, 'Between Islam and Catholicism: Bosnian Franciscan Missionaries in Turkish Hungary', The

Catholic Historical Review, 89 (2003), 409-433, 411, 415, and 427.

liii Ibid.

liv See Miguel Leon-Portilla, Bernardino de Sahagún: First Anthropologist (Oklahoma, 2012), and J. Jorge Klor de Alva, H. B. Nicholson and Eloise Quiñones Keber, The Work of Bernardino de Sahagún, Pioneer Ethnographer of Sixteenth-Century Aztec Mexico (Albany, 1988).

Iv Walden Browne, Sahagún and the Transition to Modernity (Norman, 2000), 8.

Ivi See Philip P. Boucher, Cannibal Encounters: Europeans and Island Caribs, 1492-1763 (Baltimore: John Hopkins, 2009).

Ivii Toribio Motolinía, History of the Indians of New Spain, E. Forster ed. (Berkeley, 1950), 189.

Iviii For example, Gerónimo de Mendieta, Historia eclesiástica indiana, ed. Joaquin Garcia Icazbalceta (Mexico D.F., 1870), Book 3, Chapter 50, 311.

lix Landa, Relacion de Las Cosas de Yucatan, 74 and 67. Toribio de Benavente o Motolinía, Historia de los Indios de la Nueva España, ed. Chávez Hayhoe (Mexico D.F., 1941), also described the shared poverty of the Amerindians and Franciscans.

Ix Motolinía, E. Forster ed., 137.

Ixi Oroz Codex, 310.

Ixii Oroz Codex, 310.

Ixiii Oroz Codex, 311.

lxiv See L. Hanke All Mankind Is One: a Study of the Disputation Between Bartolomé De Las Casas and Juan Ginés De Sepúlveda in 1550 on the Intellectual and Religious Capacity of the American Indians (DeKalb, 1994).

Ixv 'Orders Given to the Twelve', in Kenneth Mills and William B. Taylor eds, Colonial Spanish America: A Documentary History (Delaware, 1998), 48-51, 49.

Ixvi Ibid.

Ixvii Chronica XXIV Generalium Ordinis Minorum, 50.

Ixviii Motolinía, E. Forster ed., 41.

Ixix Mendieta, Historia eclesiástica indiana, 185.

Ixx Bernardino de Sahagún, Florentine Codex, Book 12, The Conquest of Mexico, ed. Arthur J. O. Anderson and Charles E. Dibble (Santa Fe, 1975), 31. For the original manuscript of the Códice Florentino, see Biblioteca Laurenziana, Ms Mediceo Palatino.

Ixxi In 1577 Philip II issued a Royal Cédula for the Sahagún's volumes to be collected quietly and investigated by the Council of the Indies, Archivo General de Indias, PATRONATO, 275. The manuscript passed from Spain to Rome, where it was acquired by the Medici and deposited in their library in Florence. The Medici initially kept their acquisition secret, but artistic analysis shows that it was consulted and even influenced the design of the Uffizi ceiling; see L. Markey Imagining the Americas in Medici Florence (University Park: PA, 2016).

Ixxii Hans Baron, 'Franciscan Poverty and Civic Wealth as Factors in the Rise of Humanstic Thought', Speculum, 13:1 (1938), 1-37. For a recent contextualisation of these debates see David S. Peterson, 'Out of the Margins: Religion and Church History in Renaissance Italy', Renaissance Quarterly, 53: 3 (2000), 835- 879.

Ixxiii Alison Brown, 'Hans Baron's Renaissance', The Historical Journal, 33:2 (1990), 441-448.

Ixxiv Georg Simmel, The Stranger (1908).

Ixxv Gaston Bachelard, The Poetics of Space. 